\title{
Higher reproductive performance of a piscivorous avian predator feeding on lower trophic-level diets on ponds with shorter food chains
}

\author{
Janusz Kloskowski ${ }^{1}$ iD $\cdot$ Andrzej Trembaczowski ${ }^{2}$ Maciej Filipiuk ${ }^{3}$
}

Received: 17 March 2021 / Revised: 6 June 2021 / Accepted: 1 July 2021 / Published online: 13 July 2021

(c) The Author(s) 2021

\begin{abstract}
Variation in food-chain length may influence a predator's trophic position. In aquatic food webs, the energy value of prey typically increases with its trophic rank; hence a higher trophic-level diet is often assumed to indicate better habitat quality. We related the body and health condition of pre-fledged Red-necked Grebes Podiceps grisegena to their dietary trophic level (estimated using stable nitrogen isotope signals of feathers) in two managed pond habitats with contrasting prey availability due to different fish population structures. Ponds stocked with young, small common carp Cyprinus carpio provided abundant fish and non-fish (insects and amphibians) resources for chicks. In ponds stocked with large carp, which also supported populations of small predatory fish, the breeding success of grebes was comparatively poor, because carp exceeded the size suitable for chicks and adversely affected non-fish prey. Pre-fledged grebes were in better condition (greater body mass, lower heterophil/lymphocyte ratio) in the food-rich small-fish ponds than in the food-poor ponds dominated by large fish. Values for $\delta^{15} \mathrm{~N}$ suggested shorter food chains and a lower trophic-level diet for grebes in the food-rich ponds. Bayesian carbon and nitrogen isotope mixing models demonstrated the dietary prominence of small fish, both carp and predatory species. Betweenhabitat differences in food-chain length and grebe trophic position resulted from the higher trophic rank of small predatory fish in the food-poor ponds compared to the omnivorous carp in the food-rich ponds. Our results suggest that in aquatic food webs, feeding at higher trophic levels by strongly size-limited generalist avian predators can be associated with overall food scarcity due to the impact of fish, and thus trophic status cannot be used uncritically as a proxy for aquatic habitat quality.
\end{abstract}

Keywords Breeding performance $\cdot$ Physiological condition $\cdot$ Food webs $\cdot$ Podiceps grisegena $\cdot$ Stable isotopes

\section{Zusammenfassung}

Höhere Fortpflanzungsleistung eines fischfressenden Vogels bei Ernährung auf einer niedrigeren Trophieebene in Teichen mit kürzeren Nahrungsketten

Variation in der Länge von Nahrungsketten kann die Trophieebene eines Prädators beeinflussen. In aquatischen Nahrungsnetzen steigt der Energiewert von Beute normalerweise mit ihrer Trophieebene, weshalb oft angenommen wird, dass Nahrung auf einer höheren Trophieebene bessere Habitatqualität anzeigt. Wir haben die Köperkondition und den Gesundheitszustand von noch nicht flüggen Rothalstauchern Podiceps grisegena zu der Trophieebene ihrer Nahrung (die anhand von stabilen Stickstoffisotopensignalen in den Federn abgeschätzt wurde) in Bezug gesetzt, und zwar in zwei

Communicated by C. Barbraud.

Janusz Kloskowski

janusz6kl@gmail.com

1 Institute of Zoology, Poznań University of Life Sciences, Wojska Polskiego 71C, 60-625 Poznań, Poland

2 Institute of Physics, Maria Curie-Skłodowska University, pl. Marii Curie-Skłodowskiej 1, 20-031 Lublin, Poland

3 Department of Zoology and Nature Protection, Institute of Biological Sciences, Maria Curie-Skłodowska University, Akademicka 19, 20-033 Lublin, Poland 
gemanagten Teichhabitaten, in denen sich die Nahrungsverfügbarkeit aufgrund unterschiedlicher Fischpopulationsstrukturen unterschied. Teiche, die mit jungen, kleinen Karpfen Cyprinus carpio besetzt waren, boten reiche Fisch- und andere Beuteressourcen (Insekten und Amphibien) für die Küken. In mit großen Karpfen besetzten Teichen, die auch Populationen kleiner Raubfische aufrechterhielten, war der Bruterfolg der Taucher vergleichsweise niedrig, da die Karpfen aufgrund ihrer Größe für die Küken als Beute ungeeignet waren und sich negativ auf andere Beutetiere auswirkten. In den nahrungsreichen Teichen mit kleineren Fischen waren die noch nicht flüggen Taucher in besserer Kondition (höhere Körpermasse, niedrigeres Heterophilen-Lymphozyten-Verhältnis) als in den von größeren Fischen dominierten nahrungsarmen Teichen. Die $\delta^{15} \mathrm{~N}$-Werte deuteten auf kürzere Nahrungsketten in den nahrungsreichen Teichen hin und darauf, dass die Taucher dort Beute auf einer niedrigeren Trophieebene nutzten. Bayessche Kohlenstoff- und Stickstoffisotopenmischungsmodelle zeigten, dass kleine Fische, sowohl Karpfen als auch Raubfische, häufiger gefressen wurden. Die Unterschiede zwischen den beiden Habitaten in der Länge der Nahrungskette und der Trophieebene der Taucher waren auf die höhere Trophieebene kleiner Raubfische in den nahrungsarmen Teichen verglichen mit den omnivoren Karpfen in den nahrungsreichen Teichen zurückzuführen. Unsere Ergebnisse deuten darauf hin, dass in aquatischen Nahrungsnetzen die Nahrungsaufnahme von Beute auf höheren Trophieebenen durch stark größenlimitierte generalistische Vogelprädatoren mit einer auf den Einfluss von Fischen zurückzuführenden allgemeinen Nahrungsknappheit verbunden sein kann. Daher kann die Trophieebene nicht kritiklos als ein $\mathrm{Maß}$ für die Habitatqualität genutzt werden.

\section{Introduction}

Food web properties such as food-chain length are essential to the nature of species' interactions and their population dynamics (Pimm 1982; Post 2002a). Generalist top predators may exploit various trophic levels of food webs, depending on prey availability and profitability, and thus also compete with consumers at lower trophic rank. Prey from higher trophic levels often have higher energetic and nutritional value than prey from lower levels (Hodum and Hobson 2000; Becker et al. 2007b; van Donk et al. 2017) due to upward trophic transfer. Also, the body size of consumers typically increases with trophic level, so that fewer food items are needed to provide a given amount of energy, although the availability of large-bodied herbivorous or detritivorous prey may lead to short food chains (Layman et al. 2005). In birds, except for species with ontogenetic shifts from animal food to a herbivorous diet, feeding at higher trophic levels should be associated with greater offspring production and better condition of both adults and offspring (Forero et al. 2002; Moody et al. 2012; Lorenz et al. 2020).

In aquatic food webs, fish are usually more energy-dense and contain more nutrients than invertebrates from lower trophic levels (Massias and Becker 1990; Forero et al. 2002; Gingras and Paszkowski 2006; van Donk et al. 2017). If there are positive correlations between dietary trophic level, food quality, and the body condition of birds, researchers can make inferences about habitat quality from the trophic status of prey used within past and present ecosystems (e.g. Becker et al. 2007b; Norris et al. 2007; Farmer and Leonard 2011; St. John Glew et al. 2019). However, some marine studies have revealed that a diet consisting of organisms with relatively higher trophic status does not always correspond with better body condition in birds (Janssen et al. 2009; Cruz et al. 2012; Morrison et al. 2014). This may be explained by the greater fitness advantages of feeding on abundant but lower trophic prey in more productive habitats or time periods, as well as by certain nutritional benefits of lower trophic-level food (Hipfner et al. 2010; St. John Glew et al. 2019). Additionally, predator-prey relationships may become complicated by human impacts on food-chain length via the introduction or over-exploitation of higher-order consumers into food webs (e.g. Post 2002b; Ohba et al. 2019).

Stable isotope analysis (SIA) is a tool increasingly used in ecological studies to determine the relative importance of food sources allocated to the growth and maintenance of consumer tissues, and thus to investigate the trophic roles of individuals and species (Peterson and Fry 1987). The great advantage of SIA is that, contingent on the tissue metabolic rate, it can provide time- and source-integrated information about the relative contribution of resources to assimilated energy and nutrients (DeNiro and Epstein 1981; Hobson and Clark 1992a). Carbon and nitrogen isotopes are the most commonly used to trace the structure of food webs, as these elements may complement each other in providing insights into trophic relationships. Isotope ratios of carbon ${ }^{13} \mathrm{C} /{ }^{12} \mathrm{C}\left(\delta^{13} \mathrm{C}\right)$ can identify carbon contributions derived from different primary producers, as tissues tend to be rather poorly enriched in ${ }^{13} \mathrm{C}$ relative to food sources (Peterson and Fry 1987; Post 2002a). Owing to systematic enrichment by a factor of 2-5\%o with each trophic step (DeNiro and Epstein 1981; Minagawa and Wada 1984), ratios of nitrogen isotopes ${ }^{15} \mathrm{~N} /{ }^{14} \mathrm{~N}\left(\delta^{15} \mathrm{~N}\right)$ offer a measure of the trophic position of a species as well as food-chain length via tracking of the flow of energy and mass through various trophic pathways leading to consumers. However, ecologists using SIA must be aware of possible sources of uncertainty associated with the intricacy of trophic networks; also, physiological processes specific to growth or food deprivation can confound relationships between tissue isotopic values and diet composition (Cherel et al. 2005; Cruz et al. 2012). 
We investigated the effects of the status of fish populations (size structure and trophic rank) on the trophic position and offspring condition of a medium-sized avian generalist predator, the Red-necked Grebe Podiceps grisegena. As sizelimited foragers obtaining most of their diverse prey (macroinvertebrates, amphibians and fish) by diving, Red-necked Grebes (hereafter: grebes) strongly interact with fish (Fjeldså 1982; Wagner and Hansson 1998). They feed upon small fish, but fish may function as a competitor for shared food and, especially at larger body size, exert strong competitionlike pressure via non-consumptive effects on insects and amphibians (Kloskowski 2011). Grebes breed on shallow lentic waterbodies; in central Europe grebes nest mainly on artificial fish ponds, morphologically similar to small shallow lakes (Hagemeijer and Blair, 1997). Extensively managed ponds where fish populations are manipulated via fish stocking practices provide excellent settings for whole-system studies. We examined indices of individual condition of pre-fledged grebes raised either under food-abundant conditions on ponds stocked with young, small-sized common carp Cyprinus carpio (hereafter 'carp') or under food shortage on ponds with older carp, stocked at a size unavailable to chicks. Carbon and nitrogen SIA were used to assess the trophic level of prey fed to chicks and the relative food-chain length in the breeding ponds. Levels of $\delta^{13} \mathrm{C}$ and $\delta^{15} \mathrm{~N}$ were examined in feathers of the pre-fledged young, since they reflect isotopic environments occupied by young birds throughout their growth, and thus their stable isotope signals provide a time-integrated estimate of diet composition and trophic level (Hobson and Clark 1992a; Becker et al. 2007a). The proportional contribution of putative food sources to chicks' diet was estimated using mixing models in a Bayesian framework (Parnell et al. 2010). The relative proportions of the main prey categories in the diet of chicks were quantified by feeding observations and incorporated as informative priors into the mixing models. Given that grebes have greater reproductive success on ponds with small fish available as prey than in the presence of large fish (Kloskowski 2011), we expected better body condition and health in pre-fledged grebes in the former systems. We also expected higher trophic rank for prey provided to broods on ponds containing small fish, because large carp, while unavailable as food for chicks, can have a strong adverse effect on prey from various trophic levels (reviewed in Vilizzi et al. 2015).

\section{Methods}

\section{Study system}

This study, conducted between 2004 and 2013, was part of a larger research effort investigating the trophic relationships of Red-necked Grebes breeding on semi-natural ponds in eastern Poland $\left(51^{\circ} 18^{\prime}-27^{\prime} \mathrm{N} ; 2^{\circ} 16^{\prime}-25^{\prime} \mathrm{E}\right)$. The waterbodies occupied by grebes were employed for extensive fish production and could be classified into two types: 1) ponds with 'small fish', stocked with larval carp (3-4 mm total length) in late spring; 2) ponds with 'large fish' (1-yr old carp, about $11-15 \mathrm{~cm}$ length in early spring). The ponds varied in area (2-8 ha) and in the amount of emergent vegetation along the shorelines, but were otherwise morphologically comparable (functional design, profile, mean depth about $0.9-1.2 \mathrm{~m}$ ). Biomass stocking densities in spring were also similar among ponds of each type, i.e., practically negligible in ponds with small fish (but reaching about $50 \mathrm{~kg} /$ ha by mid-July) and about $100-200 \mathrm{~kg} / \mathrm{ha}$ in ponds with large carp.

Most ponds were routinely filled in spring and drained in autumn each year; however, some ponds with older/larger fish held water into a second consecutive year, following stocking with small fish in the previous year. Ponds received water from precipitation and from adjacent rivers through a fine-meshed screen to exclude wild fish. However, cohorts of young, small predatory fish developed in ponds that held water for a longer time, mainly Gibel Carp Carassius gibelio, Pike Esox lucius and Perch Perca fluviatilis. Pond managers estimated that late in the growing season the total of these species represented less than $5 \%$ of the fish biomass in the ponds with large carp; this would correspond to less than $20 \%$ of the fish biomass available to grebes in the ponds with small carp. In ponds containing small fish, which were filled shortly before stocking, wild fish were unlikely to be important during the birds' breeding season, as there was little time for these fishes to reach significant numbers and sizes suitable for avian consumption. Ponds with small fish provided abundant fish prey for grebe broods ('food-rich habitat'); the rapid growth of young carp (which achieved a total length of about 50-60 $\mathrm{mm}$ by the end of June) did not outpace the increasing prey ingestion capabilities of chicks. Given that the upper limit for prey size is about 2.5 times their bill length, adult grebes are physically capable of eating fish of up to $120-140 \mathrm{~mm}$ in length, while newlyhatched young are restricted to prey $<30 \mathrm{~mm}$. Additionally, ponds stocked with small fish were colonized extensively by macroinvertebrates and amphibians. In ponds with large carp ('food-poor habitat'), these fish outgrew the size range that chicks could consume and adversely affected non-fish prey resources of grebes, resulting in low provisioning rates to chicks (on average three times less prey biomass than on food-rich ponds) and poor fledging success (Kloskowski 2011). We assumed that all investigated broods relied on food resources within their natal ponds; while at an advanced brood stage some grebe parents from poor territories may fly to nearby food-rich ponds to obtain prey (Kloskowski 2011), the chicks sampled for isotope analyses were not observed to be fed with prey obtained outside the natal pond. Grebes settling on the food-poor ponds were presumably unable to 
respond to the changing food conditions; pairs breeding on these ponds were of comparable individual quality to pairs on food-rich ponds (Kloskowski et al. 2017). Thus, body size and physiological condition of chicks could be examined in relation to food conditions, independent of the quality of the parents.

\section{Field sampling and condition indices}

Breeding grebes arrived from wintering areas throughout April; early broods hatched in late May. Nests were visited to determine hatching dates and thus the age of the sampled individuals (to within $\pm 1-2$ days); broods were regularly observed for at least 6-7 weeks after hatching to establish the final number of fledglings. Pre-fledged young (at least 3 weeks old) were captured by night lighting at $2300-0230 \mathrm{~h}$ between 12 June and 31 July each year (typically 1-4 individuals sampled per year in each type of pond habitat), sexed via DNA isolated from blood taken from the brachial vein, and ringed with unique metal and colour combinations (for details, see Kloskowski et al. 2006). Body mass and bill length (from the distal tip to the corner of the mouth) were measured. Fresh unheparinized blood, collected immediately upon capture, was used to prepare smears for differential white blood cell counts. Slides with smears were air-dried and stained with May-Grünwald and Giemsa reagents. Underwing secondary median coverts were collected for SIA, dried, and stored in envelopes.

Overall, 42 pre-fledged young (27 individuals from food-rich and 15 from food-poor habitat) were used in the analyses; however, blood smears were not collected from three chicks raised on the food-rich ponds. Feathers for SIA were additionally collected from four chicks found freshly dead (age 14-32 days) in the food-poor ponds (post-mortem examination pointed to malnutrition as the primary underlying cause of death).

Body mass and heterophil/lymphocyte ratio were used as indices of chick condition. To account for differences in chick age at sampling, mass data were fitted to a Gompertz curve, using measurements obtained from a larger sample of 84 chicks (in the third week of life or later) captured in the study area between 1997 and 2014; relative body mass was calculated for each chick by dividing the mass measured at sampling by the predicted value from the Gompertz function (Tjørve and Tjørve 2010). The heterophil/lymphocyte ratio $(\mathrm{H} / \mathrm{L})$ was used because these were the two most abundant groups of immune cells. $\mathrm{H} / \mathrm{L}$ has become a widely used tool in behavioural and ecological research as a simple measure of long-term stress, including food and nutritional deprivation (Gross and Siegel 1983; Totzke et al. 1999; Lobato et al. 2005), with a slow response time to capture and handling stress (Vleck et al. 2000; Cirule et al. 2012). The reliability of the $\mathrm{H} / \mathrm{L}$ ratio as an indicator of poor feeding conditions has been well demonstrated in chicks (Lobato et al. 2005; Bańbura et al. 2013; González-Medina et al. 2016), although less consistently for breeding adults (Suorsa et al. 2004; Kloskowski et al. 2017). The H/L ratio was determined on dried blood smears by counting 200 leukocytes using highviscosity immersion oil; a higher value of the ratio indicates greater stress levels. Typically, two blood smears were taken from each bird and an average leucocyte count was used; however, slides with low-quality smears were excluded. There was a high degree of correspondence between assessments of two smears taken from the same individual (Pearson $r=0.88, P<0.001, n=21$ ).

\section{Stable isotope analyses}

Major prey items eaten by pre-fledged young were identified by parental feeding observations. Observational data were complemented by examination of the alimentary tracts of chicks collected dead, because small-sized prey, such as insects, were difficult to taxonomically identify from visual observations (Kloskowski 2004). Food sources included various groups of insects (Dytiscidae, Hemiptera and Odonata), amphibians (anuran tadpoles), and fish (see Table 1 for a detailed list of prey groups). Each study year, putative prey sources of grebes were collected opportunistically from late May through July; carp were also provided by the pond operators. We did not attempt to include all prey of grebes in analyses, but only sampled the main groups common in the ponds during the brood stage. Data were combined across years due to low sample sizes within each year. We assumed that given pond management procedures, including regular pond drainage and refilling, isotopic signatures of primary producers that supported the pond food webs did not change significantly over the study period (Kloskowski and Trembaczowski 2015).

Prey samples were frozen, dried and homogenized in a mortar. Insects and tadpoles were used whole, while shells were removed from snails to obtain carbonate-free tissues. Samples of white muscles were dissected from fish. Grebe feathers were cut into small pieces, washed with acetone and ethyl alcohol to remove surface contamination, and airdried at room temperature. As lipid content varies within and between tissues, and lipids are more ${ }^{13} \mathrm{C}$-depleted than proteins, lipid removal improves interpretation of $\delta^{13} \mathrm{C}$ signals, but it may alter $\delta^{15} \mathrm{~N}$ signals (Peterson and Fry 1987; Sweeting et al. 2006). Hence, dried tissue samples were divided into two portions $(0.5-1.0 \mathrm{mg})$. Non-delipidated subsamples were used for $\delta^{15} \mathrm{~N}$ analyses, while lipids were extracted from samples for $\delta^{13} \mathrm{C}$ analyses, using chloroform as the solvent in a Soxhlet apparatus. Values for a few non-extracted samples analysed for $\delta^{13} \mathrm{C}$ were corrected by applying a taxon-specific constant obtained from analyses 
Table 1 Stable isotope values (mean \pm SD) and elemental concentrations of Red-necked Grebes prey sources in food-rich (ponds stocked with small fish) and food-poor (ponds stocked with large fish) habitats

\begin{tabular}{|c|c|c|c|c|c|c|c|c|c|c|}
\hline \multirow[b]{2}{*}{ Sources } & \multicolumn{5}{|c|}{ Food-rich ponds } & \multicolumn{5}{|c|}{ Food-poor ponds } \\
\hline & $N$ & $\delta^{13} \mathrm{C}(\% \circ)$ & $\delta^{15} \mathrm{~N}(\% o)$ & $\% \mathrm{C}$ & $\% \mathrm{~N}$ & $n$ & $\delta^{13} \mathrm{C}(\% o)$ & $\delta^{15} \mathrm{~N}(\% \circ)$ & $\% \mathrm{C}$ & $\% \mathrm{~N}$ \\
\hline Small insects and tadpoles & $14 / 26$ & $-28.4 \pm 1.9$ & $5.0 \pm 1.3$ & 41.1 & 8.3 & $10 / 6$ & $-29.0 \pm 2.4$ & $4.7 \pm 0.6$ & 46.8 & 9.5 \\
\hline Predatory insects & 10 & $-28.5 \pm 2.7$ & $7.5 \pm 1.1$ & 44.0 & 10.9 & 12 & $-28.2 \pm 1.4$ & $7.2 \pm 0.9$ & 43.7 & 11.1 \\
\hline Common Carp & 10 & $-26.9 \pm 1.8$ & $6.9 \pm 1.4$ & 44.9 & 11.1 & 12 & $-27.0 \pm 1.1$ & $7.3 \pm 0.8$ & 44.9 & 13.6 \\
\hline Small predatory fish & & & & & & 8 & $-25.9 \pm 2.6$ & $10.1 \pm 1.7$ & 44.2 & 17.1 \\
\hline Grebe (feathers) & 27 & $-25.7 \pm 2.1$ & $10.4 \pm 1.2$ & & & 15 & $-26.2 \pm 1.8$ & $13.0 \pm 0.9$ & 46.1 & 14.6 \\
\hline
\end{tabular}

'Small insects' were Coleoptera, Hemiptera (Ilyocoris cimicoides) and larval Odonata, all $\leq 10 \mathrm{~mm}$ body length

Tadpoles were Pelobates fuscus, Hyla orientalis and Pelophylax sp. Samples for food-poor ponds contained only Pelophylax tadpoles, because other local late-breeding amphibians were largely absent from these ponds

'Predatory insects' were predatory Coleoptera (>30 mm length), Notonecta, Corixidae and larval Anisoptera

Common Carp Cyprinus carpio were young-of-the-year, small-sized individuals in food-rich ponds and one-year-old large fish in food-poor ponds. Small predatory fish were Carassius gibelio, Esox lucius and Perca fluviatilis. Fish ranged from 40 to $70 \mathrm{~mm}$ total length

of both lipid-extracted and non-treated subsets of samples (Sweeting et al. 2006). Feathers were not delipidated.

Analyses of $\delta^{13} \mathrm{C}$ were performed using a dual-inlet system triple-collector mass spectrometer (Mass Spectrometry Laboratory of Maria Curie-Skłodowska University, Lublin, Poland). The $\delta^{15} \mathrm{~N}$ of the samples was measured by Elemental Analysis-Isotope Ratio Mass Spectrometry at the IsoAnalytical Laboratory (Cheshire, UK). Results are reported relative to internationally accepted standards; Vienna PeeDee belemnite (VPDB) and atmospheric nitrogen (AIR) were used for carbon and nitrogen, respectively.

\section{Parental feeding observations}

To estimate the relative contribution of the main prey items to the chick diet, which can be used as prior information in stable isotope mixing models (see Parnell et al. 2010), data on parental food deliveries collected from 31 pairs (20 broods on food-rich ponds and 11 on food-poor ponds) were analysed. As food conditions were uniform within habitats, the analyses also included observations of broods that were not sampled for SIA, but reared on the ponds where food sources and other broods were sampled; data on parental feeding and SIA results, as well as chick body condition, were available from 11 broods. We included only broods in which parental deliveries identified to the main food categories used in the isotopic mixing models (see below) constituted $\geq 95 \%$ of prey received by chicks. At least one adult was individually colour-ringed in all pairs to preclude repeated sampling of the same individuals. Observations (2-6 h sessions, conducted at least weekly) began at the completion of brood hatching and continued for 6 weeks (note that some broods were attended by parents longer, up to 9 weeks).
Observations were performed from unobtrusive locations using a $20-60 \times$ spotting scope; with the exception of the first post-hatching days, the families spent most of the time easily observable on open water. We attempted to identify parental deliveries to the finest taxonomic category possible; however, insects could typically be identified only to basic taxonomic levels and classified by size classes. Prey-length estimates, assessed relative to the length of the feeding parent's bill, were converted to wet biomass using equations derived from measurements of prey species collected in the study ponds (for detailed methods see Kloskowski 2004, 2011). Later, prey items were assigned to functional groups which proved to be isotopically distinct (see below). Small carp were the principal food in the food-rich habitat. On food-poor ponds, although the densities of small predatory fish at a size available to young grebes were much lower than those of carp in food-rich ponds, they formed a substantial part of the chick diet, but large carp were never observed to be consumed (Fig. 1). The relative importance of the main food categories changed over the chick-rearing period. Fish contribution increased from small proportions in the first weeks post-hatching to on average about $90 \%$ of the estimated ingested biomass in the food-rich habitat and about $65 \%$ in the food-poor habitat in the sixth week post-hatching (Fig. 1).

\section{Statistical analyses}

The indices of chick condition and $\delta^{13} \mathrm{C}$ and $\delta^{15} \mathrm{~N}$ levels were compared between the two habitats using general linear mixed effects models (GLMMs) fitted by restricted maximum likelihood (REML) methods. Habitat quality (foodrich vs food-poor ponds) was included as a fixed categorical term. Since the trophic position of grebe chicks was likely to be affected by their body-and-bill-size-dependent ability to 
Fig. 1 Proportion of biomass across prey categories fed by parents to Red-necked Grebe chicks during the first six weeks post-hatching on (a) food-rich ponds stocked with small carp, $n=20$ broods and (b) food-poor ponds containing large carp and low densities of small predatory fish (mainly Carassius gibelio, Esox lucius and Perca fluviatilis), $n=11$ broods. The prey categories shown for each habitat correspond to those used in isotopic mixing models (see Fig. 3). Contributions of other or unidentified prey $(\leq 5 \%)$ were omitted (a)

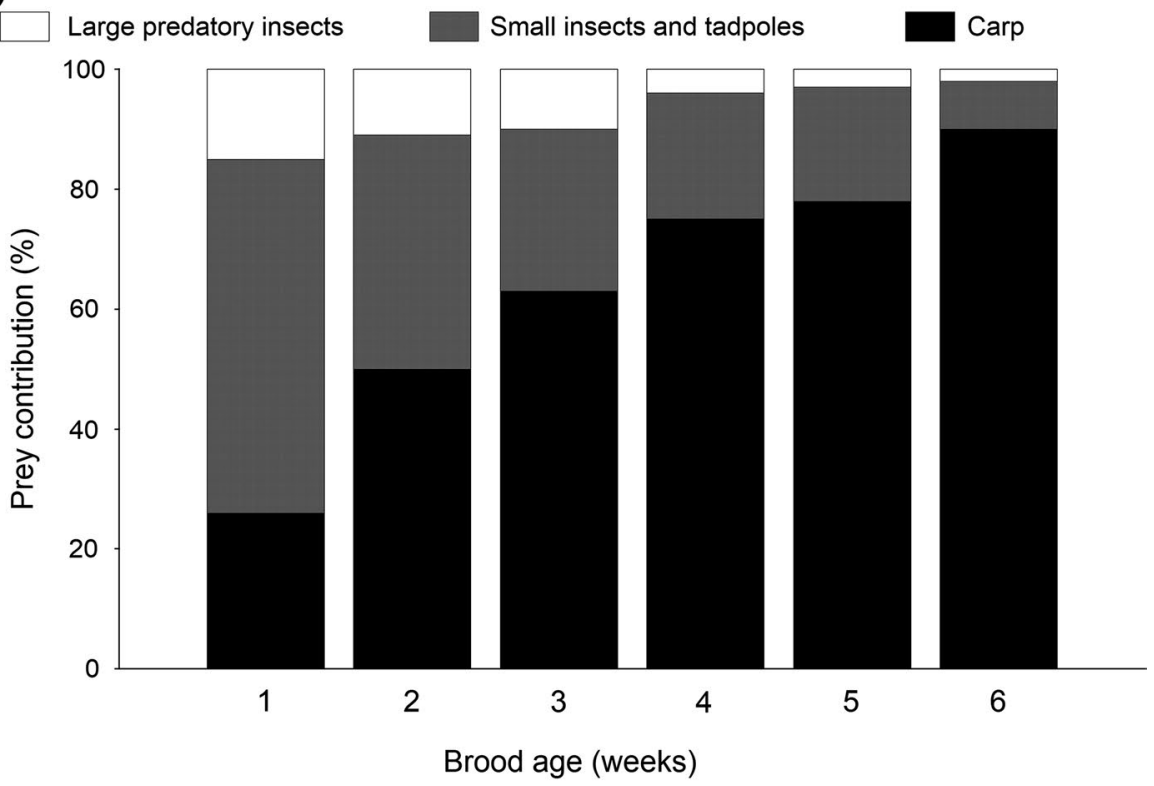

(b)

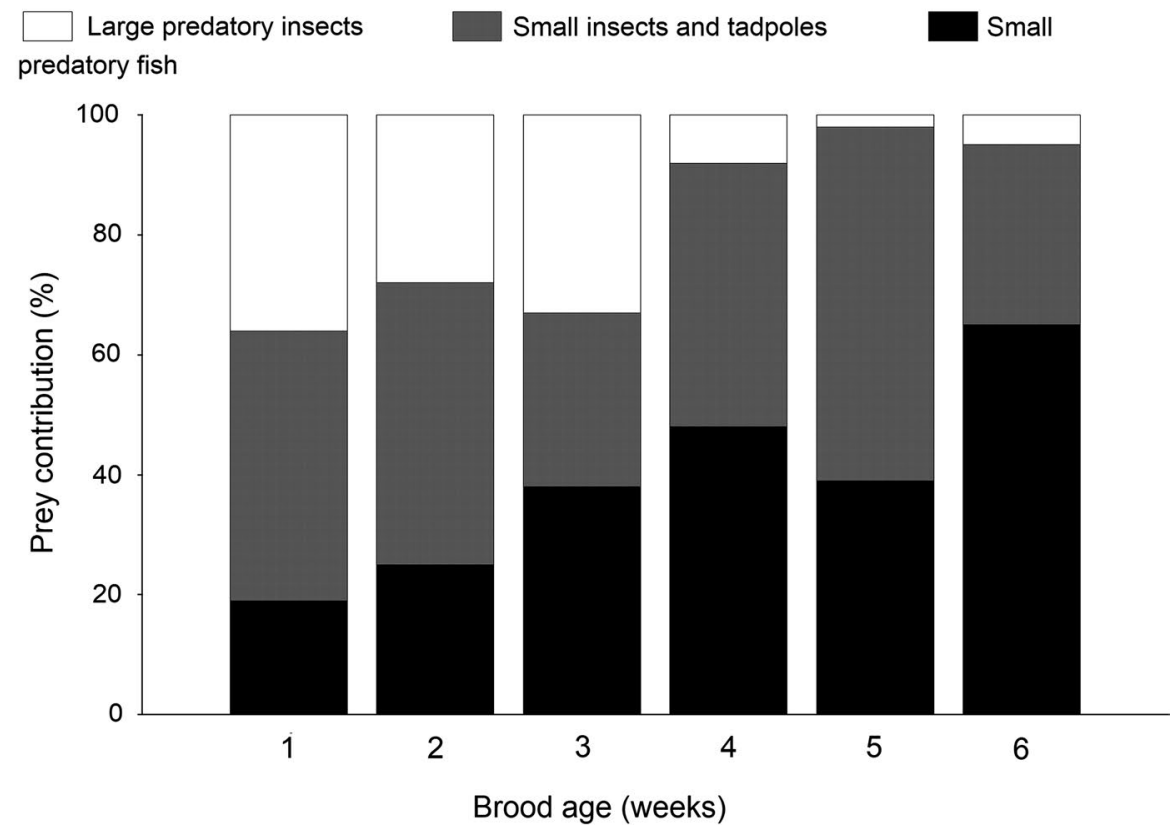

handle and ingest prey (Fjeldså 1982), the other fixed term in the $\delta^{13} \mathrm{C}$ and $\delta^{15} \mathrm{~N}$ models was raw body mass at sampling. Raw body mass was used because it was strongly correlated with (and thus a reliable proxy for) relative body mass, bill length and chick age (Pearson correlation, all $P<0.001$ ), whereas, unlike relative body mass or bill length, it did not significantly differ between the two habitats. However, in models for $\mathrm{H} / \mathrm{L}$ ratios, chick age (expressed in days posthatching) was used instead of mass, as leukocyte differentials may change with age due to ontogenetically changing investment in the immune system (Masello et al. 2009; Dehnhard et al. 2011; Jakubas et al. 2015). Although sexual dimorphism in grebes is slight (Kloskowski et al. 2006), chick sex was introduced as an additional fixed factor in the GLMMs for relative body mass and H/L because patterns of growth, as well as the relative proportions of leukocytes, may differ between sexes (Campo and Davila 2002; Bellebaum et al. 2018). Brood size, expressed as the number of chicks (range 1-4) that survived at least the first two weeks post-hatching, was initially included because some studies have demonstrated reduced growth rate or lower body condition in larger broods, as adult birds may pass on the costs of increased parental effort to their offspring (Ilmonen et al. 2003). Brood size was significantly greater in the food-rich 
habitat (see "Results"), but was positively related to both body condition measures, indicating that the favourable food conditions overwhelmed the possible adverse effects of greater brood size (see also Kloskowski 2019). Consequently, it was omitted from analyses. Similarly, study year was initially considered but then dropped as insignificant.

As some broods were represented by two chicks in the samples, brood identity was used as a random factor in the GLMMs; averaged values of feather isotope ratios were used in the other analyses. Study ponds were aggregated in four clusters (sites) scattered at distances of $10-50 \mathrm{~km}$ apart, with the same fish management practices but different water supplies. Therefore we checked for potential inter-site differences in $\delta^{13} \mathrm{C}$ and $\delta^{15} \mathrm{~N}$ baseline values using snails Lymnea stagnatilis (7-8 snails from each pond cluster) as consumers at the base of the food web (Post 2002a; Quevedo et al. 2009). No significant variation was found among pond clusters in Lymnea $\delta^{13} \mathrm{C}$ or $\delta^{15} \mathrm{~N}$ signals, but Lymnea snails did not provide reasonable baseline estimates, as their $\delta^{15} \mathrm{~N}$ values were typically higher than those of non-predatory insects and exhibited pronounced individual variation (see also Doi et al. 2010). We additionally used a smaller sample (3-4 individuals per site) of herbivorous leaf beetles Donacia cinerea (Chrysomelidae), which represented the lowest trophic level sampled from the ponds $\left(\delta^{15} \mathrm{~N} \approx 3.2 \%\right.$; Kloskowski and Trembaczowski 2015), and their $\delta^{13} \mathrm{C}$ and $\delta^{15} \mathrm{~N}$ also did not differ among pond clusters. Consequently, raw (not baseline-corrected) $\delta^{13} \mathrm{C}$ and $\delta^{15} \mathrm{~N}$ values were treated as measures of the trophic position of grebes and their food sources. Nevertheless, we used site (pond cluster) as an additional random term in the GLMMs on the isotopic levels in feathers. Owing to the small number of predictors (most of the models were bivariate), inference was based on models including all predictor terms; univariate models provided the same conclusions. Interactions were not examined. All GLMMs were run in Genstat v. 15 (VSN International).

Prey-proportion densities in the pre-fledging diet of grebes were assessed using Bayesian mixing models (Stable Isotopes Analysis in R, SIAR package; Parnell et al. 2010). On the assumption that basal producers were isotopically consistent from pond to pond, we ran mixing models for the two habitat types, not only for individual ponds or pond clusters. We used roughly the same number of samples of individual food sources from each pond cluster. K-mean cluster analysis was applied to assign prey to isotopically distinct functional groups according to their taxonomic and trophic relatedness (Table 1). Insects were assigned to two food-source groups: 'small insects' occupying a relatively low-trophic level (these were additionally pooled with tadpoles due to similar isotopic mean values) and mid-trophic level 'predatory insects' (Table 1). Assignment of insects to groups was occasionally functional rather than taxonomic; both groups contained dytiscids and Anisoptera larvae based on body size, $\leq 15 \mathrm{~mm}$ vs $\geq 30 \mathrm{~mm}$ body length. On the other hand, water boatmen and backswimmers (Corixidae and Notonecta; Heteroptera), despite their relatively small body size, were classified as predatory insects based on their consistently high $\delta^{15} \mathrm{~N}$ signatures. The third food source was small carp in the food-rich habitat and small predatory fish in the food-poor habitat. The pooled mean and pooled standard deviation (SD) for each food-source group were used in SIAR models.

Based on parental feeding observations, means of the proportional contributions of the food sources were calculated on a weekly basis for each observed pair, and then the sample means and in the case of fish the SD of all sample means were entered as informative priors (the SIAR package allows only one SD to be given in prior information; Parnell et al. 2010).

Diet-feather fractionation factors for grebes were not known, so we used averaged literature values $\left(1.2 \%\right.$ o for ${ }^{13} \mathrm{C}$ and $3.6 \%$ or ${ }^{15} \mathrm{~N}$ ) for piscivorous birds (Becker et al. 2007a) with $\mathrm{SD}=0.5 \%$. Since resource mixing approaches are sensitive to the assumptions made about fractionation values (Phillips et al. 2014; Kadye et al. 2020), the robustness of our models was assessed by changing the fractionation factors by one SD. The average concentrations of carbon and nitrogen in food sources were calculated and used in models.

\section{Results}

\section{Chick body condition}

The sampled broods enjoyed higher fledging success in food-rich habitat than in food-poor habitat ( $t$ test, $t=2.45$, $\mathrm{df}=30, P=0.020)$; in all broods in the latter habitat at least one chick died, presumably due to poor nutrition. The prefledged young from the food-rich habitat had greater relative body mass and a lower $\mathrm{H} / \mathrm{L}$ ratio than young from the foodpoor habitat (Fig. 2). Chick sex and age as fixed predictors did not significantly affect body condition (Table 2 ).

\section{Trophic relationships in the ponds}

As determined by the $\delta^{15} \mathrm{~N}$ signatures of chick feathers, grebes were the top predators of the pond food webs in both habitats (Table 1). Young carp held an intermediate trophic position between small and predatory insects in ponds dominated by small fish. The ${ }^{15} \mathrm{~N}$ enrichment of large carp in ponds stocked with large fish did not differ from that of carp in ponds with small fish. Small predatory fish present in ponds dominated by large carp occupied a distinctly higher trophic level than carp (Table 1). Small and predatory insects showed similar $\delta^{13} \mathrm{C}$ values in both habitats, but the ${ }^{13} \mathrm{C}$ enrichment between insect and grebe 


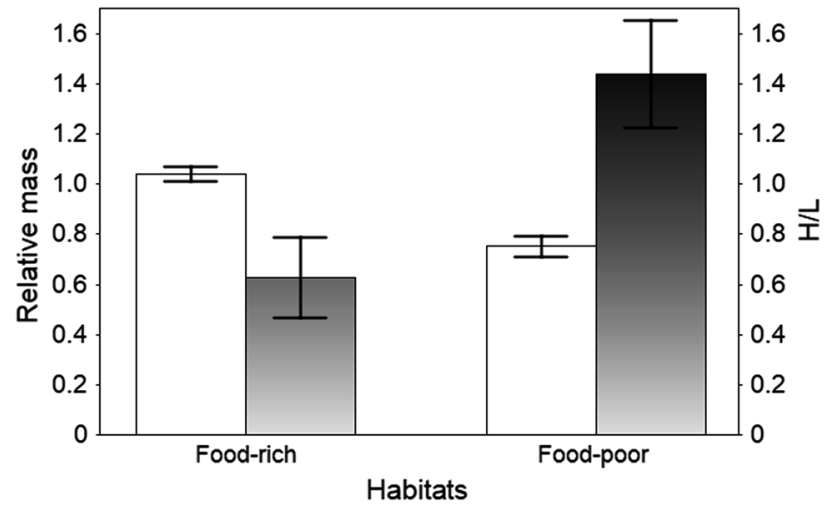

Fig. 2 Restricted maximum likelihood (REML) predicted means ( \pm standard errors) for relative body mass (open bars), calculated using Gompertz growth curve models, and heterophil/lymphocyte ratio (filled bars) of pre-fledged Red-necked Grebes in two pond habitats differing in food availability

tissues was about $3 \%$ in both habitats. The $\delta^{13} \mathrm{C}$ values in the feathers of young grebes did not differ between the two habitats, whereas $\delta^{15} \mathrm{~N}$ values were higher in food-poor habitat (by $2.6 \%$ on average), indicating that chick diet here was dominated by higher trophic-level prey and that food chains were longer in ponds with large carp (Tables 1 and 3). Within the range of chick age covered by the study,
${ }^{13} \mathrm{C}$ or ${ }^{15} \mathrm{~N}$ enrichment of feathers did not change as body mass increased (Table 3).

Feathers collected from starved chicks were consistently more depleted in ${ }^{15} \mathrm{~N}$ (range 8.4-11.1\%o) than those from chicks that survived in the food-poor habitat (Mann-Whitney test, $\mathrm{U}_{12,4}=0, P=0.004$ ).

\section{Isotopic mixing models}

Bayesian isotopic mixing models indicated that fish was the greatest contributor to chick diets in both habitats, although the $95 \%$ credible intervals for the proportion of fish were relatively wide, especially for the food-rich habitat (Fig. 3). Including priors from parental feeding observations did not reduce uncertainty for the composition of grebe diets in the food-rich habitat (credible intervals changed by up to $2 \%$ ) compared to the uninformed model (S1), but resulted in 10-37\% narrower $95 \%$ credible intervals for estimates in the model for the food-poor habitat.

Analyses of the sensitivity of the informed SIAR models showed that estimates for the food-poor habitat were robust to variation in fractionation factors, as the fractionation-dependent shifts in source contribution (5 and $95 \%$ probability values) were less than $5 \%$. In the models for the food-rich habitat, estimates for the dietary contribution of large predatory insects also varied within 5\%; reducing the fractionation factors by $1 \mathrm{SD}$
Table 2 Results of the fixed effects portions of general linear mixed effects models relating body mass and heterophil/ lymphocyte ratio (H/L) of prefledged red-necked grebes to food abundance in their habitat

\begin{tabular}{llllll}
\hline Response variable & Predictor & Effect (SE) & $F$ & $d f$ & $P$ \\
\hline Relative body mass & $\begin{array}{l}\text { Food abundance } \\
\text { (rich vs poor }\end{array}$ & $0.000,-0.290(0.049)$ & 34.71 & $1,28.5$ & $<0.001$ \\
& $\quad$ habitat) & & & \\
& Sex & $0.065(0.043)$ & 2.30 & $1,36.6$ & 0.138 \\
H/L & $\begin{array}{l}\text { Food abundance } \\
\quad \text { (rich vs poor }\end{array}$ & $0.000,0.833(0.247)$ & 11.35 & $1,24.8$ & 0.002 \\
& $\quad$ habitat) & & & \\
& Sex & $0.330(0.221)$ & 2.23 & $1,32.8$ & 0.145 \\
& Age (days) & $0.013(0.011)$ & 1.48 & $1,31.3$ & 0.233 \\
\hline
\end{tabular}

Chick sex and, in the model for $\mathrm{H} / \mathrm{L}$ ratio also age, were included as additional fixed variables

Brood identity was a random factor

Standard errors of effect estimates are given in brackets

Table 3 Results of the fixed effects portions of general linear mixed effects models relating stable isotope values for carbon and nitrogen in feathers of pre-fledged red-necked grebes to food abundance and body mass

\begin{tabular}{lllrrr}
\hline Response variable & Predictor & Effect (SE) & $F$ & $d f$ & $P$ \\
\hline$\delta^{13} \mathrm{C}$ & Food abundance (rich vs poor habitat) & $0.000,-0.666(0.928)$ & 0.51 & $1,3.5$ & 0.518 \\
& Body mass (g) & $0.003(0.002)$ & 1.69 & $1,38.4$ & 0.202 \\
$\delta^{15} \mathrm{~N}$ & Food abundance (rich vs poor habitat) & $0.000,2.280(0.619)$ & 13.57 & $1,24.8$ & $<0.001$ \\
& Body mass (g) & $-0.001(0.001)$ & 0.62 & $1,37.7$ \\
\hline
\end{tabular}

Study site (pond cluster) and brood identity were random factors

Standard errors of effect estimates are given in brackets 
Fig. 3 Proportional contribution of prey categories to the pre-fledging diet of Red-necked Grebes as determined by SIAR (Stable Isotopes Analysis in R) mixing models. Boxes of decreasing thickness and shading reflect $25 \%, 75 \%$ and $95 \%$ credibility intervals of the maximum-likelihood values for (a) food-rich habitat (ponds stocked with small carp and supporting abundant amphibian and invertebrate prey) and (b) food-poor habitat (ponds dominated by large carp, containing low densities of small predatory fish; large carp was omitted from the analyses because they were too large to serve as food for chicks). Informative priors were included: in the food-rich habitat, small carp $=63 \%$, small insects and tadpoles $=30 \%$, and predatory insects $=7 \%$; in the food-poor habitat, small predatory fish $=41 \%$, small insects and tadpoles $=46 \%$, and predatory insects $=13 \%$
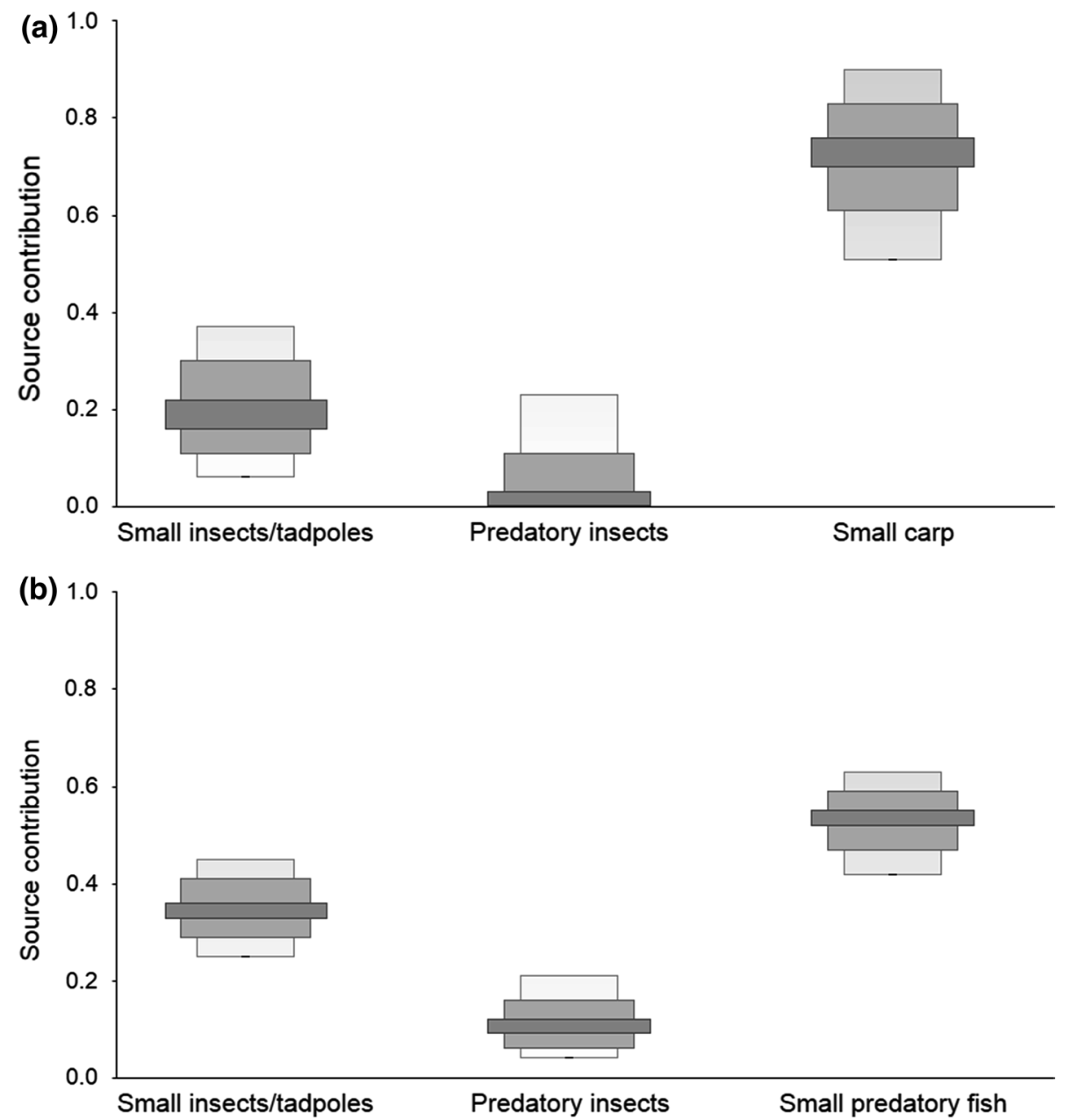

increased estimates for the proportion of fish in the assimilated diets relative to the contribution of small insects/tadpoles by $2-16 \%$, whereas increasing values by $1 \mathrm{SD}$ lowered proportions of fish and increased those of small insects/tadpoles by $2-17 \%$.

\section{Discussion}

\section{Differences in chick body condition and trophic position}

As expected, our results demonstrated better body and health condition of young birds raised on the food-rich ponds, even though parents had to feed larger broods in this habitat. The higher $\mathrm{H} / \mathrm{L}$ ratios may be explained by the physiological consequences of nutritional stress in the food-poor habitat (e.g. Suorsa et al. 2004; Jakubas et al. 2015; González-Medina et al. 2016). Within-brood competition, including aggression associated with food deprivation (see also Vleck et al. 2000; Ilmonen et al. 2003), may have acted as a proximate factor, but some of the pre-fledged chicks examined in the food-poor habitat were the only survivors from their broods.
We found no significant differences in feather $\delta^{13} \mathrm{C}$ values between grebes from the two habitats; since ponds differing in fish status were interspersed and had similar morphometry, this result was expected, as the pond food webs were likely to be supported by the same primary producers (see also McParland et al. 2010). These shallow flat-bottomed ponds are largely littoral habitat, so the number of trophic pathways supported by different primary producers is restricted relative to deeper, more complex water bodies (cf. Post 2002a; Vander Zanden and Vadeboncoeur 2002; Syväranta et al. 2006). On the other hand, as aquatic insects and amphibians migrate across ecosystem boundaries, ponds receive large supplies of allochthonous subsidies, which may be influenced by the fish status of the ponds (Carpenter et al. 2005; Kloskowski and Trembaczowski 2015). The $\delta^{13} \mathrm{C}$ values showed some increase from insects/tadpoles to fish and grebes, but this may reflect trophic enrichment rather than differences in carbon sources (Hobson and Clark 1992b; Paszkowski et al. 2004). The greater $\delta^{15} \mathrm{~N}$ values of feathers of young from the ponds with large carp indicated that their diet included a greater proportion of high trophic-level prey than the diet of chicks from the food-rich habitat. This 
contradicted our prediction that the use of upper trophiclevel prey would be correlated with better chick condition. Since grebes were the top predators with the highest $\delta^{15} \mathrm{~N}$ values in both pond habitats, these results also imply longer food chains in the ponds containing large fish. The difference in trophic position was significant, but given the average isotopic increment of about 3.4\% between trophic levels in aquatic ecosystems (Minagawa and Wada 1984; Post 2002a), it was less than one trophic level. Overall, the relatively narrow $\delta^{15} \mathrm{~N}$ ranges in both habitats were consistent with food webs exposed to disturbance regimes (such as temporary drainage), comprising few trophic steps, i.e., three- or fourlevel food chains (Post 2002b).

Greater $\delta^{15} \mathrm{~N}$ values in the tissues of poorly-fed chicks could potentially be explained by food deprivationinduced enrichment of ${ }^{15} \mathrm{~N}$ via catabolism of endogenous proteins and changes in amino acid distribution among tissues (Hobson and Clark 1992b; Cherel et al. 2005). However, the feathers of chicks that died from undernourishment actually had lower $\delta^{15} \mathrm{~N}$ values than chicks that survived in food-poor habitat (Kempster et al. 2007; Williams et al. 2007). Although young grebe chicks from food-poor ponds were in worse condition than those raised in food-rich ponds, food restriction may have been mitigated by clutch and brood reduction (Kloskowski 2019), and thus survivors did not attain levels of nutritional stress that alter isotopic fractionation patterns for ${ }^{15} \mathrm{~N}$ (cf. Kempster et al. 2007). Diet-tissue fractionation of $\delta^{13} \mathrm{C}$ appears less responsive to food restriction (Hobson and Clark 1992b; Williams et al. 2007).

\section{Fish effects on the trophic position of grebes}

The discriminatory strength of isotopic mixing models is usually low in ecosystems with a diverse array of food sources and multiple trophic connections (Phillips et al. 2014). Grebes exploit prey that represents a broad range of trophic positions, while our mixing models were based on only three sources, due to short food chains in the breeding ponds. The isotopic overlaps between sources resulted in large confidence intervals for pooled prey groups and thus presumably also in wide credible intervals around the estimates of food-source contribution, especially for the foodrich habitat with its more diverse food resources (cf. Kloskowski and Trembaczowski 2015; Robinson et al. 2018). Any isotopic heterogeneity among the primary producers of the study ponds could represent an additional source of variation. Mixing models and observed diet could not be directly compared because food composition determined from feeding observations was expressed as weekly averages, while isotopic signals of feathers represent nutrients integrated over the entire feather growth period (Hobson and Clark 1992a). Still, the mixing models, including those without informative priors, provided support for our inference from observations of parental provisioning that small fish were the main contributor to chick tissue formation in both habitats, and thus responsible for the trophic position of grebes. Potential differences in the estimation of the dietary importance of small insects and tadpoles in the food-rich habitat and of large predatory insects in the food-poor habitat likely resulted from issues in source partitioning in the isotopic models, while data from direct observations could suffer from difficulties with the taxonomic identification and size estimation of smaller prey items (Kloskowski 2004).

Although the pond communities were manipulated by human management, pond hydroperiod patterns and trophic structure (dominance of single species or single cohort populations of fish) were similar to those of natural ponds, differing in permanence but exposed to ecosystem 'resetting' by catastrophic events, such as drought or winter hypoxia (Wellborn et al. 1996). Communities of lentic, shallow water bodies are usually shaped by environmental perturbations, with fish assemblages often dominated by either small (young-age cohorts or generally smallbodied species) or large fish, including piscivores (e.g. Paszkowski and Tonn 2000; McParland et al. 2010). The presence of fish, especially predatory species, can lengthen food chains of aquatic ecosystems (Vander Zanden et al. 1999; Ohba et al. 2019) and influence prey availability and habitat selection by waterbirds (Wagner and Hansson 1998; Nummi et al. 2016). In the present study, predatory fish, despite their small individual size, were more enriched in ${ }^{15} \mathrm{~N}$ than either carp size/age classes (by nearly a trophic level) or predatory insects, and thus could significantly lengthen pond food chains (see also McParland et al. 2010; Newbrey et al. 2012).

A moderate increase in food-chain length due to the presence of small-bodied fish (positioned high in the food web), and inclusion of these fish in the diet, can be beneficial for piscivorous birds, depending on their gape constraints (van Eerden et al. 1993; McParland et al. 2010). However, a significant presence of large fish, even apparently non-competing species such as carp that do not specialize in foraging on mobile prey (Sibbing 1988), may exclude small and medium-sized avian predators from ecosystems (Haas et al. 2007; Maceda-Veiga et al. 2017). Large carp, like small/ young carp, were actually mid-trophic consumers, presumably because they forage on benthic prey, which occupy lowtrophic levels, and consume a lot of detritus and vegetable matter, including cereal grains provided as a supplemental feed source in cultured ponds (Sibbing 1988; Kloskowski 2011). However, in our study system it was principally the middle-out effects (affecting many trophic levels through a combination of top-down and bottom-up influences) of large carp (see also Vilizzi et al. 2015; Kaemingk et al. 2017) that brought about food shortage for grebes in the ponds 
stocked with large carp, rather than the influence of predatory fish at high trophic levels, represented by relatively low densities of fish with small body size (Kloskowski 2011). Non-fish resources were a key component of the grebe diet in the critical early, post-hatching stage; however, large fish can act as an effective (non-consumptive) 'intimidator' deterring insects and amphibians from ovipositing in ponds (Kloskowski 2011, 2020; cf. Wellborn et al. 1996). Grebes, prohibited from extensive consumption of low-trophic level resources, were forced to rely on high trophic-level prey of limited availability (cf. Layman et al. 2005). A further lengthening of the pond food chains by the establishment of populations of large piscivorous fish would result in stronger competitive pressure for grebes (van Eerden et al. 1993; Newbrey et al. 2012).

\section{Prey trophic level vs habitat quality}

In our study system, grebe chicks fed a lower trophic-level diet in the food-rich habitat were obviously in better body condition, because they received food at a substantially higher rate (Kloskowski 2011) than chicks consuming higher trophic-level prey in the food-poor habitat. Besides the profitability trade-offs associated with the costs of capture, handling and digestibility, lower trophic prey may also provide a high energetic return and/or contain important nutrients (Morrison et al. 2014; van Donk et al. 2017; Lorenz et al. 2020). While fish are usually more rewarding prey than invertebrates or amphibian larvae for birds (Massias and Becker 1990; Gingras and Paszkowski 2006; Ledwoń and Neubauer 2017), the calorific values of temperate freshwater fish species are not necessarily related to their trophic status (Schreckenbach et al. 2001; Vilches et al. 2019). The omnivorous Common Carp has typically higher energetic content and may have greater net profitability as prey than trophically higher predatory fish (Scherz and Senser 1994; Schreckenbach et al. 2001), although the energy density of fish can change radically through ontogeny (Meakins 1976).

Analysis of $\delta^{15} \mathrm{~N}$ is a valuable means of delineating dietary sources and trophic level, because it provides an energy flow-based continuous measure of the trophic steps between the primary sources and the consumer (Minagawa and Wada 1984; Vander Zanden et al. 1999). As the energetic and nutritional value of prey in many food webs tends to increase with each trophic step, it is tempting for ecologists to use trophic levels of feeding estimated with stable isotopes as a universal proxy for habitat quality in terms of food resources, in that decline in $\delta^{15} \mathrm{~N}$ values is explained by reduced feeding opportunities (e.g. Norris et al. 2007; Wiley et al. 2013; Blight et al. 2015; Tawa and Sagawa 2021). Our study shows that small or medium-sized avian generalists may fare better when the food chain is shorter and they rely on abundant/productive prey of relatively lower trophic levels (Pimm 1982; Vander Zanden et al. 1999). Importantly, the abundance of such low-rank prey may depend not only on the absence of competitive high-trophic level consumers, but also on the absence of potential competitors which are lower in the trophic hierarchy but invulnerable to predation (Pimm 1982). Fish are well known for their singularly adverse effects on macroinvertebrates, which provide vital resources for waterbirds (Eriksson 1979; Nummi et al. 2016). Our findings have conservation implications in that they show that waters with short food chains containing or potentially containing fish, yet not trophically dominated by fish (e.g. without species that can outgrow predator gape limits), may offer highly suitable breeding habitats for sizelimited generalist avian predators feeding to a large extent on fish (van Eerden et al. 1993; Haas et al. 2007; Maceda-Veiga et al. 2017). For a range of relatively small avian generalists, such as terns, small-medium grebes, and facultatively piscivorous ducks, habitat suitability may depend not on fish presence/absence, but on the size structure of fish assemblages, often characterized by dominance of either large, especially piscivorous, fish or small-bodied species (Sjöberg 1989; Paszkowski and Tonn 2000). More generally, we caution against drawing conclusions on habitat quality based on prey trophic-level estimates alone (see also Morrison et al. 2014), since the trophic rank and profitability of prey need not be correlated in food webs where trophic connections are complicated by omnivory of key consumers, size-structured interactions, and competition between taxonomically distant species. This caution may especially apply to studies of long-term historical trends, for which data on food webs are usually crude (Blight et al. 2015; English et al. 2018; Tawa and Sagawa 2021).

Supplementary Information The online version contains supplementary material available at https://doi.org/10.1007/s10336-021-01910-z.

Acknowledgements We thank J. Krogulec, M. Polak, P. Wencel and numerous volunteers for their field assistance and E. Kaczanowska for reading the white blood cell slides. Thanks also to two anonymous reviewers for constructive feedback on the manuscript. The research was supported by grants from the State Committee for Scientific Research (3PO4F03623) and from the Polish Ministry of Science and Higher Education (MNiSW 2P04G05030). The work presented here was approved by the Local Ethical Commission (Lublin) and the Polish Ministry of the Environment.

Data availability Available from the first author on reasonable request.

Open Access This article is licensed under a Creative Commons Attribution 4.0 International License, which permits use, sharing, adaptation, distribution and reproduction in any medium or format, as long as you give appropriate credit to the original author(s) and the source, provide a link to the Creative Commons licence, and indicate if changes were made. The images or other third party material in this article are included in the article's Creative Commons licence, unless indicated otherwise in a credit line to the material. If material is not included in the article's Creative Commons licence and your intended use is not 
permitted by statutory regulation or exceeds the permitted use, you will need to obtain permission directly from the copyright holder. To view a copy of this licence, visit http://creativecommons.org/licenses/by/4.0/.

\section{References}

Bańbura J, Skwarska J, Bańbura M, Glądalski M, Hołysz M, Kaliński A, Zieliński P (2013) Spatial and temporal variation in heterophilto-lymphocyte ratios of nestling passerine birds: comparison of blue tits and great tits. PLoS ONE 8:e74226

Becker BH, Newman SH, Inglis S, Beissinger SR (2007a) Dietfeather stable isotope $\left(\delta^{15} \mathrm{~N}\right.$ and $\left.\delta^{13} \mathrm{C}\right)$ fractionation in Common Murres and other seabirds. Condor 109:451-456

Becker BH, Peery MZ, Beissinger SR (2007b) Ocean climate and prey availability affect the trophic level and reproductive success of the Marbled Murrelet, an endangered seabird. Mar Ecol Prog Ser 329:267-279

Bellebaum J, Szostek KL, Kloskowski J (2018) Population dynamics and survival of the Red-necked Grebe Podiceps grisegena: results from a long-term study in eastern Poland. J Ornithol 159:631-641

Blight LK, Hobson KA, Kyser TK, Arcese P (2015) Changing gull diet in a changing world: a 150 -year stable isotope $\left(\delta^{13} \mathrm{C}, \delta^{15} \mathrm{~N}\right)$ record from feathers collected in the Pacific Northwest of North America. Glob Change Biol 21:1497-1507

Campo JL, Davila SG (2002) Estimation of heritability for heterophil: lymphocyte ratio in chickens by restricted maximum likelihood. Effects of age, sex, and crossing. Poult Sci 81:1448-1453

Carpenter SR, Cole JJ, Pace ML, Van de Bogert M, Bade DL, Bastviken D, Kritzberg ES (2005) Ecosystem subsidies: terrestrial support of aquatic food webs from ${ }^{13} \mathrm{C}$ addition to contrasting lakes. Ecology 86:2737-2750

Cherel Y, Hobson KA, Bailleul F, Groscolas R (2005) Nutrition, physiology, and stable isotopes: new information from fasting and molting penguins. Ecology 86:2881-2888

Cirule D, Krama T, Vrublevska J, Rantala MJ, Krams I (2012) A rapid effect of handling on counts of white blood cells in a wintering passerine bird: a more practical measure of stress? J Ornithol 153:161-166

Cruz LL, McGill RAR, Goodman SJ, Hamer KC (2012) Stable isotope ratios of a tropical marine predator: confounding effects of nutritional status during growth. Mar Biol 159:873-880

Dehnhard N, Quillfeldt P, Hennicke JC (2011) Leucocyte profiles and $\mathrm{H} / \mathrm{L}$ ratios in chicks of Red-tailed Tropicbirds reflect the ontogeny of the immune system. J Comp Physiol B 181:641-648

DeNiro MJ, Epstein S (1981) Influence of diet on the distribution of nitrogen isotopes in animals. Geochim Cosmochim Acta 45:341-351

Doi H, Yurlova NI, Kikuchi E, Shikano S, Yadrenkina EN, Vodyanitskaya SN, Zuykova EI (2010) Stable isotopes indicate individual level trophic diversity in the freshwater gastropod Lymnaea stagnalis. J Moll Stud 76:384-388

English PA, Green DJ, Nocera JJ (2018) Stable isotopes from museum specimens may provide evidence of long-term change in the trophic ecology of a migratory aerial insectivore. Front Ecol Evol $6: 14$

Eriksson MO (1979) Competition between freshwater fish and goldeneyes Bucephala clangula (L.) for common prey. Oecologia 41:99-107

Farmer RG, Leonard ML (2011) Long-term feeding ecology of Great Black-backed Gulls (Larus marinus) in the northwest Atlantic: 110 years of feather isotope data. Can J Zool 89:123-133
Fjeldså J (1982) The adaptive significance of local variations in the bill and jaw anatomy of North European red-necked grebes Podiceps grisegena. Ornis Fenn 59:84-98

Forero MG, Hobson KA, Bortolotti GR, Donázar JA, Bertellotti M, Blanco G (2002) Food resource utilisation by Magellanic penguin evaluated through stable isotope analysis: segregation by sex and age and influence of offspring quality. Mar Ecol Prog Ser 234:289-299

Gingras BA, Paszkowski CA (2006) Feeding behavior and modeled energetic intake of common loon (Gavia immer) adults and chicks on small lakes with and without fish. Hydrobiologia 567:247-261

González-Medina E, Castillo-Guerrero JA, Santiago-Quesada F, Villegas A, Masero JA, Sánchez-Guzmán JM, Fernández G (2016) Variation in parental rearing expenditure triggers short-term physiological effects on offspring in a long-lived seabird. Ibis 158:305-314

Gross WB, Siegel HS (1983) Evaluation of the heterophil/lymphocyte ratio as a measure of stress in chickens. Avian Dis 27:972-979

Haas K, Köhler U, Diehl S, Köhler P, Dietrich S, Holler S, Jensch A, Niedermaier M, Vilsmeier J (2007) Influence of fish on habitat choice of water birds: a whole-system experiment. Ecology 88:2915-2925

Hagemeijer EJM, Blair MJ (eds) (1997) The EBCC atlas of European breeding birds: their distribution and abundance. T and A D Poyser, London

Hipfner JM, Dale J, McGraw KJ (2010) Yolk carotenoids and stable isotopes reveal links among environment, foraging behavior and seabird breeding success. Oecologia 163:351-360

Hobson KA, Clark RG (1992a) Assessing avian diets using stable isotopes I: turnover of ${ }^{13} \mathrm{C}$ in tissues. Condor $94: 181-188$

Hobson KA, Clark RG (1992b) Assessing avian diets using stable isotopes II: factors influencing diet-tissue fractionation. Condor 94:189-197

Hodum PJ, Hobson KA (2000) Trophic relationships among Antarctic fulmarine petrels: insights into dietary overlap and chick provisioning strategies inferred from stable-isotope $\left(\delta^{15} \mathrm{~N}\right.$ and $\left.\delta^{13} \mathrm{C}\right)$ analyses. Mar Ecol Prog Ser 198:273-281

Ilmonen P, Hasselquist D, Langefors A, Wiehn J (2003) Stress, immunocompetence and leukocyte profiles of pied flycatchers in relation to brood size manipulation. Oecologia 136:148-154

Jakubas D, Wojczulanis-Jakubas K, Kośmicka A (2015) Factors affecting leucocyte profiles in the little auk, a small Arctic seabird. J Ornithol 156:101-111

Janssen MH, Arcese P, Kyser TK, Bertram DF, McFarlane-Tranquilla L, Williams T, Norris D (2009) Pre-breeding diet, condition, and timing of breeding in a threatened seabird, the marbled murrelet Brachyramphus marmoratus. Mar Ornithol 37:33-40

Kadye WT, Redelinghuys S, Parnell AC, Booth AJ (2020) Exploring source differences on diet-tissue discrimination factors in the analysis of stable isotope mixing models. Sci Rep 10:15816

Kaemingk MA, Jolley JC, Paukert CP, Willis DW, Henderson K, Holland RS, Lindvall ML (2017) Common carp disrupt ecosystem structure and function through middle-out effects. Mar Freshw Res 68:718-731

Kempster B, Zanette L, Longstaffe FJ, MacDougall-Shackleton SA, Wingfield JC, Clinchy M (2007) Do stable isotopes reflect nutritional stress? Results from a laboratory experiment on song sparrows. Oecologia 151:365-371

Kloskowski J (2004) Food provisioning in Red-necked Grebes (Podiceps grisegena) at common carp (Cyprinus carpio) ponds. Hydrobiologia 525:131-138

Kloskowski J (2011) Consequences of the size structure of fish populations for their effects on a generalist avian predator. Oecologia 166:517-530 
Kloskowski J (2019) An avian equivalent of selective abortion: postlaying clutch reduction under resource limitation. Behav Ecol $30: 864-871$

Kloskowski J (2020) Better desiccated than eaten by fish: distribution of anurans among habitats with different risks to offspring. Freshw Biol 65:2124-2134

Kloskowski J, Trembaczowski A (2015) Fish reduce habitat coupling by a waterbird: evidence from combined stable isotope and conventional dietary approaches. Aquat Ecol 49:21-31

Kloskowski J, Grela P, Krogulec J, Gąska M, Tchórzewski M (2006) Sexing Red-necked Grebes Podiceps grisegena by molecular techniques and morphology. Acta Ornithol 41:176-180

Kloskowski J, Kaczanowska E, Krogulec J, Grela P (2017) Hematological indicators of habitat quality: erythrocyte parameters reflect greater parental effort of Red-necked Grebes under ecological trap conditions. Condor 119:239-250

Layman CA, Winemiller KO, Arrington DA, Jepsen DB (2005) Body size and trophic position in a diverse tropical food web. Ecology $86: 2530-2535$

Ledwoń M, Neubauer G (2017) Offspring desertion and parental care in the Whiskered Tern Chlidonias hybrida. Ibis 159:860-872

Lobato E, Moreno J, Merino S, Sanz JJ, Arriero E (2005) Haematological variables are good predictors of recruitment in nestling pied flycatchers (Ficedula hypoleuca). Ecoscience 12:27-34

Lorenz TJ, Kozma JM, Cunningham PG (2020) The influence of climate and habitat on stable isotope signatures and the isotopic niche of nestling White-headed Woodpeckers (Dryobates albolarvatus). Ecol Evol 10:9827-9840

Maceda-Veiga A, López R, Green AJ (2017) Dramatic impact of alien carp Cyprinus carpio on globally threatened diving ducks and other waterbirds in Mediterranean shallow lakes. Biol Conserv 212:74-85

Masello JF, Choconi RG, Helmer M, Kremberg T, Lubjuhn T, Quillfeldt P (2009) Do leucocytes reflect condition in nestling burrowing parrots Cyanoliseus patagonus in the wild? Comp Biochem Physiol A 152:176-181

Massias A, Becker PH (1990) Nutritive value of food and growth in Common Tern Sterna hirundo chicks. Ornis Scand 21(3):187-194

McParland CE, Paszkowski CA, Newbrey JL (2010) Trophic relationships of breeding red-necked Grebes (Podiceps grisegena) on wetlands with and without fish in the Aspen Parkland. Can J Zool 88:186-194

Meakins RH (1976) Variations in the energy content of freshwater fish. J Fish Biol 8:221-224

Minagawa M, Wada E (1984) Stepwise enrichment of ${ }^{15} \mathrm{~N}$ along food chains: further evidence and the relation between $\delta^{15} \mathrm{~N}$ and animal age. Geochim Cosmochim Acta 48:1135-1140

Moody AT, Hobson KA, Gaston AJ (2012) High-arctic seabird trophic variation revealed through long-term isotopic monitoring. J Ornithol 153:1067-1078

Morrison KW, Bury SJ, Thompson DR (2014) Higher trophic level prey does not represent a higher quality diet in a threatened seabird: implications for relating population dynamics to diet shifts inferred from stable isotopes. Mar Biol 161:2243-2255

Newbrey JL, Paszkowski CA, Gingras BA (2012) Trophic relationships of two species of grebe on a prairie lake based on stable isotope analysis. Hydrobiologia 697:73-84

Norris DR, Arcese P, Preikshot D, Bertram DF, Kyser TK (2007) Diet reconstruction and historic population dynamics in a threatened seabird. J Appl Ecol 44:875-884

Nummi P, Väänänen VM, Holopainen S, Pöysä H (2016) Duck-fish competition in boreal lakes-a review. Ornis Fenn 93:67-76

Ohba SY, Suzuki K, Sakai Y, Shibata JY, Okuda N (2019) Effects of irrigation system alterations on the trophic position of a threatened top predator in rice-field ecosystems. Freshw Biol 64:1737-1746
Parnell A, Inger R, Bearhop S, Jackson AL (2010) Source partitioning using stable isotopes: coping with too much variation. PLoS ONE 5:e9672

Paszkowski CA, Tonn WM (2000) Community concordance between the fish and aquatic birds of lakes in northern Alberta, Canada: the relative importance of environmental and biotic factors. Freshw Biol 43:421-437

Paszkowski CA, Gingras BA, Wilcox K, Klatt PH, Tonn WM (2004) Trophic relations of the Red-necked Grebe on lakes in the western boreal forest: a stable-isotope analysis. Condor 106:638-651

Peterson BJ, Fry B (1987) Stable isotopes in ecosystem studies. Ann Rev Ecol Syst 18:293-320

Phillips DL, Inger R, Bearhop S, Jackson AL, Moore JW, Parnell AC, Semmens BX, Ward EJ (2014) Best practices for use of stable isotope mixing models in food web studies. Can J Zool 92:823-835

Pimm SL (1982) Food webs. Chapman \& Hall, New York

Post DM (2002a) Using stable isotopes to estimate trophic position: models, methods, and assumptions. Ecology 83:703-718

Post DM (2002b) The long and short of food-chain length. Trends Ecol Evol 17:269-277

Quevedo M, Svanbäck R, Eklöv P (2009) Intrapopulation niche partitioning in a generalist predator limits food web connectivity. Ecology 90:2263-2274

Robinson BG, Franke A, Derocher AE (2018) Stable isotope mixing models fail to estimate the diet of an avian predator. Auk 135:60-70

Scherz H, Senser F (1994) Food composition and nutrition tables. Medpharm, Stuttgart

Schreckenbach K, Knösche R, Ebert K (2001) Nutrient and energy content of freshwater fishes. J Appl Ichthyol 17:142-144

Sibbing FA (1988) Specializations and limitations in the utilization of food resources by the carp, Cyprinus carpio: a study of oral food processing. Environ Biol Fish 22:161-178

Sjöberg K (1989) Time-related predator/prey interactions between birds and fish in a northern Swedish river. Oecologia 80:1-10

St John Glew K, Wanless S, Harris MP et al (2019) Sympatric Atlantic puffins and razorbills show contrasting responses to adverse marine conditions during winter foraging within the North Sea. Mov Ecol 7:33

Suorsa P, Helle H, Koivunen V, Huhta E, Nikula A, Hakkarainen H (2004) Effects of forest patch size on physiological stress and immunocompetence in an area-sensitive passerine, the Eurasian Treecreeper (Certhia familiaris): an experiment. Proc R Soc Lond B 271:435-440

Sweeting CJ, Polunin NVC, Jennings S (2006) Effects of chemical lipid extraction and arithmetic lipid correction on stable isotope ratios of fish tissues. Rapid Commun Mass Spectrom 20:595-601

Syväranta J, Hämäläinen H, Jones R (2006) Within-lake variability in carbon and nitrogen stable isotope signatures. Freshw Biol 51:1090-1102

Tawa K, Sagawa S (2021) Stable isotopic analysis of stuffed specimens revealed the feeding habits of Oriental Storks Ciconia boyciana in Japan before their extinction in the wild. J Ornithol 162:193-206

Tjørve KMC, Tjørve E (2010) Shapes and functions of bird-growth models: how to characterise chick postnatal growth. Zoology 113:326-333

Totzke U, Fenske M, Hüppop O, Raabe H, Schach N (1999) The influence of fasting on blood and plasma composition of herring gulls (Larus argentatus). Physiol Bioch Zool 72:426-437

van Donk S, Camphuysen KCJ, Shamoun-Baranes J, van der Meer J (2017) The most common diet results in low reproduction in a generalist seabird. Ecol Evol 7:4620-4629

van Eerden MR, Piersma T, Lindeboom R (1993) Competitive food exploitation of smelt Osmerus eperlanus by great crested grebes 
Podiceps cristatus and perch Perca fluviatilis at Lake IJsselmeer, The Netherlands. Oecologia 93:463-474

Vander Zanden MJ, Vadeboncoeur Y (2002) Fishes as integrators of benthic and pelagic food webs in lakes. Ecology 83:2152-2161

Vander Zanden MJ, Shuter BJ, Lester N, Rasmussen JB (1999) Patterns of food chain length in lakes: a stable isotope study. Am Nat 154:406-416

Vilches A, Arizaga J, Miranda R (2019) Does the Common Kingfisher (Alcedo atthis) select the most energetic fish prey? Ornis Fenn 96:33-40

Vilizzi L, Tarkan AS, Copp GH (2015) Experimental evidence from causal criteria analysis for the effects of common carp Cyprinus carpio on freshwater ecosystems: a global perspective. Rev Fish Sci Aquac 23:253-290

Vleck CM, Vertalino N, Vleck D, Bucher TL (2000) Stress, corticosterone and heterophil to lymphocyte ratios in free-living Adélie penguins. Condor 102:392-400
Wagner BMA, Hansson L-A (1998) Food competition and niche separation between fish and the red-necked grebe Podiceps grisegena (Boddaert, 1783). Hydrobiologia 368:75-81

Wellborn GA, Skelly DK, Werner EE (1996) Mechanisms creating community structure across a freshwater habitat gradient. Ann Rev Ecol Syst 27:337-363

Wiley AE, Ostrom PH, Welch AJ, Fleischer RC, Gandhi H, Southon JR, James HF (2013) Millennial-scale isotope records from a wide-ranging predator show evidence of recent human impact to oceanic food webs. Proc Natl Acad Sci USA 110:8972-8977

Williams CT, Buck CL, Sears J, Kitaysky AS (2007) Effects of nutritional restriction on nitrogen and carbon stable isotopes in growing seabirds. Oecologia 153:11-18

Publisher's Note Springer Nature remains neutral with regard to jurisdictional claims in published maps and institutional affiliations. 